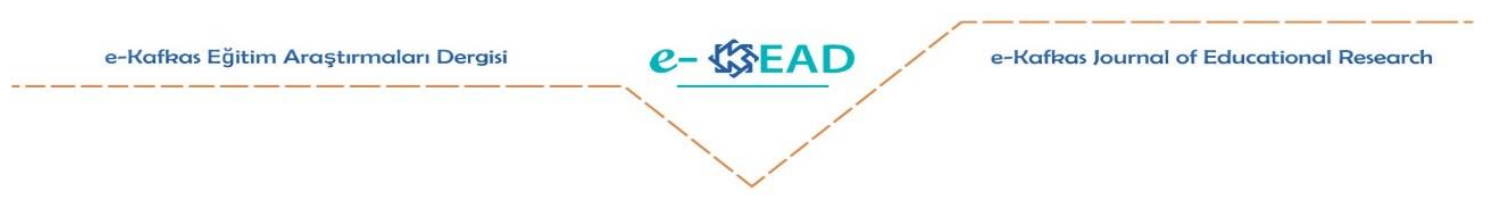

\title{
Sekizinci Sınıf Öğrencilerinin Kareköklü İfadeler Konusunda Matematiksel Dil Kullanım Düzeyleri ve Dile İlişkin Görüşleri
}

\author{
Süha Yılmaz ${ }^{1}$ (D) $ه$ Sidar Güzel $^{2}$ (iD
}

Atıf: Yılmaz, S. ve Güzel, S. (2020) Sekizinci sınıf öğrencilerinin karaköklü ifadeler konusundaki matematiksel dil kullanım düzeyleri ve dile ilişkin görüşleri. e- Kafkas Eğitim Araştırmaları Dergisi, 7, 282-302. doi: 10.30900/kafkasegt.733078

Araştırma Makalesi
Geliș Tarihi:06.05.2020

Kabul Tarihi: 29.11 .2020

$\ddot{O} \mathbf{z}$

$\mathrm{Bu}$ araştırmanın amacı sekizinci sınıf öğrencilerinin kareköklü ifadeler konusunda matematiksel dili kullanabilme düzeyleri ile matematiksel dil kullanımına yönelik görüşlerini belirlemek ve bunları bazı değişkenler açısından incelemektir. Ayrıca kareköklü ifadeler konusunda matematiksel dili kullanabilme düzeyleri ile matematiksel dil kullanıma yönelik görüşleri arasındaki ilişkinin incelenmesi amaçlanmıştır. Araştırmanın örneklemini Doğu Anadolu Bölgesinde yer alan bir ilin Milli Eğitim Müdürlüğüne bağlı iki farklı devlet okulunda eğitim gören toplam 114 sekizinci sınıf öğrencisi oluşturmaktadır. Araştırmanın amacı doğrultusunda yedi farklı alt problem belirlenmiş ve çalışmada Betimsel Tarama Modeli tercih edilmiştir. Veri toplama aracı olarak araştırmacı tarafından geliştirilen ve uzman görüşü alınarak hazırlanmış, açık uçlu ve çoktan seçmeli soruların yer aldığı "Kareköklü İfadeler Başarı Testi" ve alan diline yönelik görüşlerini belirlemek amacıyla geçerlilik ve güvenirlik çalışması gerçekleştirilmiş 21 maddelik likert tipi "Matematiksel Dil Ölçeği" kullanılmıştır. Verilerin analizinde, frekans dağılımı, betimsel istatistikler, korelasyon ve bağımsız örneklemler $t$ testi uygulanmıştır. Araştırmanın sonucunda öğrencilerin kareköklü ifadeler konusunda matematiksel dili kullanımlarında eksiklerin olduğu ve bunların geliştirilmesi gerektiği, matematiksel dili kullanım düzeylerinin cinsiyete göre anlamlı farklılık göstermediği ve matematiksel dil kullanım düzeyleri ile matematik başarıları arasında orta düzeyde pozitif bir ilişki olduğu tespit edilmiştir. Ayrıca öğrencilerin matematiksel dil kullanımına yönelik olumlu görüş̧e sahip oldukları, cinsiyet değiş̧keni açısından anlamlı farklılık göstermediği, matematiksel dil kullanımına ilişkin görüşleri ile matematik başarıları arasında düşük düzeyde bir ilişki olduğu görülmüştür.

Anahtar Sözcükler: Matematik alan dili, kareköklü ifadeler, tutum, düzey, başarı

\begin{abstract}
The purpose of this study is to determine the level of eighth grade students' ability to use mathematical language on square-rooted expressions and their views on mathematical language use and to examine them in terms of some variables. In addition, it was aimed to examine the relationship between the level of using mathematical language in terms of square-rooted expressions and their views on using mathematical language. The sample of the study consists of a total of 114 eighth grade students studying at two different public schools affiliated to the Directorate of National Education in a province located in the Eastern Anatolia Region. In line with the purpose of the study, seven different sub-problems were determined and the Descriptive Scan Model was preferred in the study. As the data collection tool, the "Square-Rooted Expressions Achievement Test", which was developed by the researcher and prepared by taking expert opinion, was used to include open-ended and multiple-choice questions, and the 21-item Likert-type "Mathematical Language Scale" was used to determine the validity and reliability study of the field language. Language Scale" was used. Frequency distribution, descriptive statistics, correlation and independent samples t test were used to analyze the data. As a result of the study, it was determined that there are deficiencies in the use of mathematical language in terms of square-rooted expressions and these need to be improved, their level of mathematical language use does not differ significantly according to gender, and there is a moderate positive relationship between mathematical language use levels and mathematics achievement. In addition, it was observed that the students had a positive opinion on the use of mathematical language, there was no significant difference in terms of gender variable, and there was a low level of relationship between their views on mathematical language use and their mathematics achievement.
\end{abstract}

Keywords: Mathematical language, square rooted expressions, attitude, level, success

\footnotetext{
${ }^{1}$ Sorumlu yazar, Profesör Doktor, suha.yilmaz@ deu.edu.tr, Dokuz Eylül Üniversitesi, Buca Eğitim Fakültesi, Türkiye

2 Dokuz Eylül Üniversitesi
} 


\section{Giriş}

İnsanların düşüncelerinin alt yapısı dil aracılığıyla gerçekleşmektedir (Doğan ve Güner, 2012). Matematiğin kendine özgü sözcükleri, terimleri, dili ve ifade şeklinin olduğu, aynı şekilde bu sözcüklerin bir kısmının yalnızca kendi iç dünyasında var olan ya da kullanılan ifadeler olduğu gibi diğer bir kısmı ise sosyal hayatta kullanılan kelimeler olabilir (Aydın ve Yeşilyurt, 2007). Cümleleri meydana getiren kelimeler, cümleye farklı anlamlar katmaktadır bu nedenle matematiği öğretirken ve sınıf içinde iletişim kurarken dilin yapısının, kullanım biçiminin ve aynı şekilde dilin özelliklerinin irdelenmesi gerekmektedir çünkü iletişimin gerçekleşmesinde önemli araçlardan biri dildir (Yaman ve Gültekin, 2015). Dil her zaman sese bağlı olgu olmayıp, işaretlerin kullanımı amacıyla işlev görür. Baykul (2016) bazı sembolleri içine alan bir dil, yaşadığımız dünyayı anlamamızda ve bulunduğumuz çevreyi geliştirmek amacıyla ihtiyaç duyduğumuz bir kaynak, bireyi mantıklı bir şekilde düşündüren bir sistem olarak matematiği tanımlamıştır. Brodie (1989)'ye göre dil, düşüncelerin ön koşulu olduğu gibi, kişilerin matematiksel yapılar ve işlemler konusunda sorgulamalarına düşüncelerini rahat ve açık bir şekilde ifade etmelerine ve buldukları sonuçları doğrulamalarına imkan vermekte yani en basit anlamda dilin bir iletişim aracı olduğu söylenebilir.

Filozof, dilbilimci, sosyolog ve psikologlar dili farklı şekillerde tanımlamışlardır. Tanımlara bakıldığında: Ergin (2008) dilin doğal bir öğe olduğunu belirterek insanların anlaşmasını sağlayan, kendine özgü kuralları olan ve bu kurallar içinde değişen, gelişen, temelinin ne zaman atıldığ1 hakkında bilgiye sahip olmadığımız gizli bir anlaşma düzeni ve seslerden örülmüş bir kurum olarak tanımlarken, Banguoğlu (2007 ) ise kişi çeşitli işaretler yaparak isteklerini anlatabilir ancak insanların düşüncelerini, isteklerini ya da amaçlarını anlatmak için kullanmış oldukları bir sesli işaretler sistemi olduğunu belirterek en etkili anlatma aracının dil olduğunu ifade etmiştir. Gencan (1966) dilin iç benliğimizin aynası olduğu belirtmiştir. Kavcar (1988) ise dili, insanları birbirine yaklaştıran düşünce aracı, kültürün temel öğesi ve toplumun millet olmasını sağlayan en önemli öğe olarak tanımlamıştır. Kaplan (2002) bireyin duygularına, düşüncelerine ve hayal dünyasına dilin yön verdiğini söylemiştir. Dil aracılığıyla gerçekleşen iletişim için ifadeler ya da cümleler, cümleler için de sözcükler kullanılmakta, sözcüklerin bir araya gelmesiyle de kavramlar tanımlanmaktadır (Akman ve Erden, 2001). İnsanların birbirleri ile sağlıklı iletişim kurmaları ancak aynı dili kullanmaları ile mümkündür. Bazı matematiksel terim ve kavramlar doğru içerikle kullanılmadığında öğrenciler bu terim ve kavramları yanlış anlayabilmekte ve farklı anlamlara getirebilmekte bu nedenle öğretmenlerin kullanmış olduğu matematiksel kavramların öğrenci için aynı anlam ifade etmesi çok önemlidir (Çalıkoğlu Bali, 2002).

Cobb, Wood ve Yackel (1994)'in belirttiği gibi matematiksel dilin kullanılmasında öğretmenlerin öğrencilerine rehberlik etmeleri gerektiğini vurgulayarak, öğretmen desteği alamayan öğrencinin matematik dilini yeterli bir şekilde kullanamayacağını ifade etmiştir çünkü matematiğin konu alanına giren bazı kavram ve sözcükler ile ilk defa karşılaşan öğrenciler bu kavram ve sözcüklere yabancı olabilmektedir bu nedenle öğretmenlerin matematik derslerinde matematiksel terimleri ve kavramları doğru bir içerikle sunmaları gerekmektedir. Sınıf içinde öğretmenlerin kullanmış oldukları matematiksel dilin çocuğun eğitim hayatı boyunca matematik bilgilerinin oluşmasında büyük bir etkiye sahip olduğundan çocuğun matematik girdisinin matematiksel dil olduğu söylenebilir (Fırat ve Dinçer, 2019). Matematiksel kavramların öğrenilmesinde büyük bir etkiye sahip olan dil, matematik dilinin doğru kullanımı, matematiksel düşüncelerin gelişiminde ve aynı zamanda matematiksel kavramların öğrenilmesinde önem arz etmektedir bundan dolayı matematiksel dilin doğru ve etkili kullanımı için matematik dilinin kurallarını iyi bir şekilde anlamalı ve bu dile ihtiyaç duyulmalıdır.

Öğretmenler, öğrencilerin sınıf içinde matematik dilini kullanarak problem kurmalarını, kurmuş oldukları problemlerin çözümüne yönelik tartışma ortamı oluşturmalarını ve aynı zamanda bu tartışmalara katılımlarını sağlamalıdır (Çalıkoğlu Bali, 2002) çünkü öğrencinin, matematik dilini kullanırken yaşamış olduğu güçlügün fark edilmesi matematiksel dilin geliştirilmesinde büyük etkiye sahiptir. Bu nedenle öğretmenin öğrencinin sınıf ortamında ya da bir problemi çözerken doğal olarak gerçekleşen tartışma ortamında kullanmış oldukları dili öğretmenin değerlendirerek bu bilgileri 
öğrenme ortamına aktarması gerekmektedir (Zazkis, 2000). Doğal olarak etkinlikleri gerçekleştirirken bireysel farklılıkların göz ardı edilmeden, öğrencinin katılımının sağlandığı tartışma ortamları, öğrencilerin ön organize edicilerini ve matematiksel dillerini ortaya çıkarmak, anlamı yapılandırmak için etkili bir yol olacaktır.

1739 sayılı Millî Eğitim Temel Kanunu'nda belirlenmiş olan Genel Amaçlar ve Temel İlkeler doğrultusunda Matematik Dersi Öğretim Programı'nın ulaşmaya çalıştığı genel amaçlar incelendiğinde görülmektedir ki insan-nesne, nesne-nesne arasındaki ilişkileri anlamlandırmak amacıyla matematiğin anlam ve dilini kullanacak ve matematiksel düşüncelerini ve mantık çerçevesinde açılamak ve bu düşüncelerini paylaşmak için matematiksel terminolojiyi ve matematiksel dili doğru kullanabileceği belirtilmiştir (MEB, 2018).

Kavramların doğru kullanılmasında ve kavramlar arasındaki ilişkiyi güçlendirmede alan dilinin etkili olduğu söylenebilir ( Köroğlu, Yavuz ve Ertem, 2003). Emre, Yazgan-Sağ, Gülkılık ve Argün (2017) çalışmasında öğretmen adaylarının kavramları anlamlandırırken ve kullanırken sembolik veya sözel dil biçimlerinden hangisine ağırlık verdiğini ortaya çıkarmayı amaçlayan çalışmada, ögretmen adayları problem çözerken daha çok sembolik dilini kullandıkları ancak matematiksel kavramları anlamlandırırken ağırlıklı olarak sözel dili kullandıkları tespit edilmiştir. Matematiğin sözel ve sembolik dili birbirinden farklı tanımlanmış olsa dahi, matematikte geniş bir şekilde kullanılan sembolik ve sözel dil biçimi içi içe geçmiş durumdadır. Çoklu temsiller (örn,sözlü anlatım, yazılı ifade, resim, grafik ve somut modeller) matematiksel dilin kullanılmasında etkili olduğu belirtilmiştir (MEB,2013). Matematiksel terimleri, kavramları veya sözcükleri anlamamızda önemli bir görev üstlenen matematiksel dil matematik eğitiminde önemli bir beceri olarak kabul edilmektedir (Sarama ve Clements, 2009). Kabael ve Baran (2016)' 1 in ortaokul matematik öğretmenleri ile gerçekleştirmiş olduğu "Matematik Öğretmenlerinin Matematiksel İletişim Becerilerinin Gelişimine Yönelik Farkındalıklarının İncelenmesi” başlıklı nitel çalışmasında tüm öğretmenlerin matematiğin bir dil olduğunun farkında oldukları, matematiksel dilin doğru ve etkin kullanılmasını bu şekilde öğrencilere örnek olunması gerektiğini düşünmelerine karşın matematiksel iletişim becerilerinin geliştirilmesi konusunda öğretmenlerin tümünün farkındalık sahibi olamadıkları sonucuna ulaşmışlardır. Otterburn ve Nicholson (1976) yaptıkları çalışmada öğrencilerin bir çok matematiksel terimi bildikleri ancak öğretmenlerin sıklıkla kullandıkları matematiksel kavramların çoğunu açıklayamadıkları görülmüştür. Araştırmanın sonuçları göstermektedir ki bu yetersizliğin farkında olmadıkları, ayrıca öğrencilerin verilen matematiksel kavramları tam olarak ifade edemedikleri gibi matematiksel kavramları anlayarak kullanmadıkları da ortaya çıkmıştır.

Bu çalışmanın amacı sekizinci sınıf öğrencilerinin kareköklü ifadeler konusunda matematiksel dili kullanabilme düzeyleri ile matematiksel dil kullanımına ilişkin görüşlerinin belirlenmesi ve çeşitli değişkenler açısından incelenmesi aynı zamanda matematiksel dili kullanabilme düzeyleri ile matematiksel dil kullanımına yönelik görüşleri arasında ilişkinin incelenmesi amaçlanmıştır. $\mathrm{Bu}$ amaca yönelik aşağıda yer alan alt problemlere yanıt aranmaya çalışılmıştır.

\section{Alt Problemler}

1) Sekizinci sınıf öğrencilerinin kareköklü ifadeler konusundaki matematiksel dili kullanabilme düzeyleri nedir?

2) Sekizinci sınıf öğrencilerinin kareköklü ifadeler konusundaki matematiksel dili kullanabilme düzeyleri ile matematik not ortalamaları arasında ilişki var mıdır?

3) Sekizinci sınıf öğrencilerinin kareköklü ifadeler konusundaki matematiksel dili kullanabilme düzeyleri onların cinsiyetlerine göre istatistiksel olarak anlamlı bir farklılık göstermekte midir?

4) Sekizinci sınıf öğrencilerinin matematiksel dil kullanımına ilişkin görüşleri nedir?

5) Sekizinci sınıf öğrencilerinin kareköklü ifadeler konusundaki matematiksel dili kullanabilme düzeyleri ile matematiksel dil kullanımına ilişkin görüşleri arasında anlamlı bir ilişki var mıdır?

6) Sekizinci sınıf öğrencilerinin matematiksel dil kullanımına ilişkin görüşleri ile matematik not ortalamaları arasında anlamlı bir ilişki var mıdır? 
7) Sekizinci sınıf öğrencilerinin Matematiksel dil kullanımına ilişkin görüşleri ile cinsiyetleri arasında istatistiksel olarak anlamlı bir farklılık göstermekte midir?

\section{Araştırma modeli}

\section{Yöntem}

Çalışmada nicel araştırma desenlerinden biri olan Betimsel Tarama Modeli kullanılmıştır. Betimsel Tarama Modeline göre oluşturulan çalışmalar bir grubun belirli özelliklerinin belirlenmesi amacıyla yapılan çalışmalardır (Büyüköztürk, Çakmak, Akgün, Karadeniz, ve Demirel, 2018). Yani var olan durumu tespit etmek amaçlanır. Çalışmada katılımcıların görüşleri ve alan dili düzeyi arasında ilişki de incelendiği için araştırma aynı zamanda ilişkisel (korelasyonel) tarama çalışmasıdır. İlişkisel tarama çalışmasında iki ya da daha fazla değişken arasındaki birlikte değişimin varlığı ve/veya derecesi, değişkenlere herhangi bir müdahalede bulunmadan incelenir (Karasar, 2011).

\section{Örneklem}

Araştırmanın örneklemini Doğu Anadolu Bölgesinde yer alan bir ilin Milli Eğitim Müdürlüğüne bağlı iki farklı devlet okulunda eğitim gören toplam 114 sekizinci sınıf öğrencisi oluşturmaktadır. Araştırmanın örnekleminin seçiminde, olasılık temelli örnekleme yöntemi içinde yer alan basit tesadüfi örnekleme yöntemi tercih edilmiştir. Basit seçkisiz örneklemede her bir örnekleme birimine eşit seçilme olasıllğ 1 verilmekte ve bu örnekleme yöntemi uzayda her bir örneklemin eşit olasılıkla seçilmesine dayanmaktadır (Çıng1, 1994). Öğrencilere ait bilgiler incelendiğinde, cinsiyetlerine göre dağılımları Tablo 1'de gösterilmiştir.

Tablo 1.

Araştırmaya Katılan Öğrencilerin Cinsiyete Göre Dăğ1lımı

\begin{tabular}{lll}
\hline Cinsiyet & $\mathrm{f}$ & $\%$ \\
\hline Kadın & 74 & 64.9 \\
Erkek & 40 & 35.1 \\
Toplam & 114 & 100.0 \\
\hline
\end{tabular}

Tablo 1 incelendiğinde çalışmaya katılan 114 ortaokul sekizinci sınıf öğrencisi grup değişkeni açısından incelendiğinde \%64.9' $\operatorname{sinın}(n=74)$ kız, \%35.1' ünün $(n=40)$ erkek olduğu sonucuna ulaşı1mıştır.

Tablo 2.

Araștırmaya Katılan Öğrencilerin Not Ortalamalarına Göre Dă̆glımı

\begin{tabular}{lll}
\hline Not Ortalamalar & $\mathrm{f}$ & $\%$ \\
\hline 1.00 & 9 & 7.9 \\
2.00 & 13 & 11.4 \\
3.00 & 30 & 26.3 \\
4.00 & 42 & 36.8 \\
5.00 & 20 & 17.5 \\
Total & 114 & 100.0 \\
\hline
\end{tabular}

Tablo 2' e göre araştırmaya katılan 114 öğrenci not ortalamaları değişkeni açısından incelendiğinde \%7.9' unun ( $n=9$ ) 1, \%11.4' inin $(n=13) 2, \% 26.3^{\prime} \operatorname{inin}(n=30) 3, \% 36.8^{\prime} \operatorname{sinin}(n=42) 4$ ve \%17.5' ünün (n=20 ) 5 not ortalamasına sahip olduğu görülmüştür.

\section{Veri Toplama Araçları}

Araştırma amacıyla iki farklı veri toplama aracı kullanılmıştır. Bunlardan birincisi; Ortaokulda eğitim gören sekizinci sınıf öğrencilerinin sayılar ve işlemler öğrenme alanında yer alan kareköklü ifadeler konusundaki matematiksel dil kullanımına yönelik becerilerini incelemek için araştırmacı tarafından 22 açık uçlu sorudan oluşan bir başarı testi geliştirilmiş. Bu araştırmada Kareköklü ifadeler alan dili başarı testinin soruları hazırlanmasında 2018 öğretim programında yer alan sekizinci 
sınıf kazanımları çerçevesinde hareket edilmiş soru maddelerinin uygunluğu ve anlaşılırlığ hakkında matematik alanında uzman iki kişinin görüşü alınmıştır. Veri toplama araçlarına pilot çalışmalar ve uzman görüşlerinin alınmasıyla son şekli verilmiştir. Yapılan bu araştırmada kareköklü ifadeler başarı testinin kapsam ve görünüş yönüyle geçerlik düzeyini belirlemek için başlıca kaynak tarama, danışman ve uzman görüşlerinden faydalanılmıştır. Araştırmacının ve uzman görüşlerinin alınarak hazırlanmış olan "Kareköklü İfadeler Başarı Testi”"nin içeriğindeki bir kısım problemde, bazı temel matematiksel kavram ve temel kuralların hem kavramsal hem de terminolojik olarak uygun şekilde ifade edilmesi istendi. Diğer bir grup problemde ise matematiksel sembollerle verilen matematiksel kural (kareköklü ifadeler ile ilgili temel özellikler) ve ilkelerin uygun matematiksel dil ile ifade edilmesi istendi ve bu test maddelerin belirlenmesinde 2018 matematik öğretim programında sayılar ve işlemler öğrenme alanı kapsamında yer alan sekizinci sınıf kareköklü ifadeler kazanımları dikkate alınmıştır.

Araştırmada kullanılan matematiksel dil ölçeği Çalıkoğlu Bali (2002)'nin geliştirdiği ölçekten yararlanılarak Akarsu (2013) tarafından geliştirilen matematiksel dil ölçeğidir. Bu ölçekte 4 boyut tanımlanmış ve bunlar "yazılı anlatım ve yazılı ödevler, sembolik anlatım, problem oluşturma ve sözlü anlatım” şeklindedir. Akarsu (2013) tarafından geçerlilik ve güvenirlik çalışması gerçekleştirilmiş 21 maddeden oluşan matematiksel dil ölçeğinde yer alan her bir maddenin gerçekleşme düzeyini belirlemek için katılımcılara "tamamen katılıyorum", "katılıyorum", "kararsızım", "katılmıyorum", "hiç katılmıyorum" seçenekleri sunulmuştur. Pilot çalışması yapılan ölçekten elde edilen verilere göre ölçeğin Cronbach Alpha güvenirlik katsayısı 0.748 olarak bulunmuştur. Matematiksel dil ölçeğinin alt boyutları olan problem çözme (0.817), sembolik anlatım (0.983), yazılı ödev (0.703) ,görselleştirme (0.694) ve kavram kullanımı (0.667) içinde Cronbach Alpha güvenirlik katsayıları hesaplanmıştır. Bu çalışmadaki örneklem üzerinde uygulanan ölçeğin alt boyutlarının ve toplam matematiksel dil puanlarının güvenirlik katsayıları ise Tablo 3'de gösterilmiştir. Bu araştırma doğrultusunda 114 öğrencinin olduğu örneklem üzerinde uygulanan ölçeğin alt boyutlarının ve toplam matematiksel dil ölçeği puanlarının güvenirlik katsayıları ise Tablo 3'de belirtilmiştir.

Tablo 3.

Matematiksel Dil Ölçeğinin Cronbach Alpha Güvenirlik Katsayısı

\begin{tabular}{llc}
\hline & Madde Numarası & Alfa Güvenirlik Katsayısı \\
\hline Problem Çözme & $5,7,10,13,16,20$ & 0.638 \\
Sembolik Anlatım & $12,15,21$ & 0.715 \\
Yazılı Ödev & $1,6,9,18$ & 0.668 \\
Görselleştirme & $2,4,14$ & 0.667 \\
Kavram Kullanımı & $3,8,11,17,19$ & 0.858 \\
Matematiksel Dil & $1,2, \ldots, 21$ & 0.908 \\
\hline
\end{tabular}

Matematiksel dil kullanımına yönelik öğrencilerin görüşlerinin alınmasında orijinal ölçekte yer aldığı şekliyle 5 alt boyut incelendiği için her bir alt boyutun Cronbach Alpha güvenirlik katsayıları hesaplanmıştır. Tablo 3'te görüldüğü gibi problem çözme, sembolik anlatım, yazılı ödev, görselleştirme ve kavram kullanımı alt boyutları için iç tutarlılık katsayıları (Cronbach Alpha) sırasıyla $0.638,0.715,0.668,0.667,0.858$ bulunmuştur. Matematiksel dil ölçeğinin toplam iç tutarlılık katsayısı hesaplandığında 0.908 olduğu görülmektedir.

\section{Verilerin Toplanması}

Öğrencilere ilk olarak kareköklü ifadeler konusundaki Matematiksel dili kullanım becerilerini incelemek amacıyla "Kareköklü İfadeler Başarı Testi" uygulanmış ardından matematiksel dil kullanımına ilişkin görüşlerini belirlemek için likert tipi "Matematiksel Dil Ölçeği”nin cevapları öğrencilerden istenmiştir. "Kareköklü İfadeler Başarı Testi" ve "Matematiksel Dil Ölçeği" uygulanmadan önce öğrencilere çalışmanın amacı hakkında gerekli açıklamalar yapılmıştır.

\section{Verilerin Analizi}


Sekizinci sınıf öğrencilerinin kareköklü ifadeler konusundaki alan dili başarılarını ölçmek amacıyla geliştirilen başarı testi ve matematiksel dile ilişkin görüşlerini belirlemek amacıyla toplanan verilerin analizine başlamadan önce öğrenciler tarafından doldurulan başarı testleri ve ölçekler tek tek incelenerek yanlış ve eksik doldurulan veri toplama araçları değerlendirme dışı bırakılmıştır. Doğru biçimde doldurulan araçlar ise bilgisayar ortamında ilgili veri analizi programına aktarılmıştır. Toplanan verilerin analizinde SPSS 23.0 bilgisayar paket programı kullanılmıştır. Tüm veriler $\mathrm{p}=0.05$ düzeyinde değerlendirilmiştir. 2018 matematik öğretim programında sayılar ve işlemler alt öğrenme alanında yer alan kareköklü ifadeler konusunda sekizinci sınıf öğrencilerinin matematiksel dili kullanabilme düzeylerini belirlemek amacıyla geliştirilmiş olan kareköklü ifadeler başarı testinde yer alan soruların analizi yapılırken sorunun çözümü ve açıklaması doğru ise iki olarak değerlendirilmekte, sadece çözümü ya da açıklaması doğru ise bir puanla değerlendirilmekte, çözümü ve açıklaması yanlış ise sıfır puanla değerlendirilmektedir. Testte yer alan sorulara ait cevaplar ayrı ayrı değerlendirilerek verilerin analizi için yüzde ve frekans hesapları kullanılmıştır. Matematiksel dil ölçeğinde yer alan her bir maddenin gerçekleşme düzeyini belirlemek için katılımcılara "tamamen katılıyorum", "katılıyorum", "kararsızım", "katılmıyorum", "hiç katılmıyorum" seçenekleri sunulmuştur. Puanlamada pozitif maddeler için "tamamen katılıyorum" seçeneği beş puanla, "kesinlikle katılmıyorum" ise bir puanla, negatif maddeler için ise "tamamen katılıyorum" seçeneği bir puanla, "kesinlikle katılmıyorum" seçeneği ise beş puanla değerlendirilmektedir.

Matematiksel Dil Ölçeği’ ne ait verilerin analizinde elde edilen puanların ortalamaları ve standart sapmaları hesaplanmıştır. Elde edilen puanların yorumlanmasında aşağıda belirtilen aralıklar ele alınmıştır.

- 4.20-5.00; “ Tamamen olumlu görüşe sahip"

- 3.40-4.19; " Olumlu görüşe sahip"

- 2.60-3.39; “ "Kısmen olumlu görüşe sahip”

- 1.80-2.59; " Olumsuz görüşe sahip"

- 1.00-1.79; “ Tamamen olumsuz görüşe sahip” (Akarsu, 2013).

Sekizinci sınıf öğrencilerinin kareköklü ifadeler başarı testinin tamamından alabileceği ortalama en yüksek not iki olarak belirlenmiş ve öğrencilerin matematiksel dil becerilerinin dört aşamada değerlendirilmesinin uygun olacağı düşünülmüştür. Buna göre, sekizinci sınıf öğrencilerinin kullandıkları matematiksel dil becerilerinin belirlenmesinde aşağıda belirtilen puan aralıkları ele alınmıştır:

- $\quad 0.00 \leq x \leq 0.49$; "önemli eksikleri var";

- $0.50 \leq x \leq 0.99$; "geliştirilmesi gerekir";

- $1.00 \leq x \leq 1.49$; "başarıll”";

- $1.50 \leq x \leq 2.00$; "oldukça başarıl1"

Kareköklü ifadeler başarı testi'nden ve Matematiksel Dil Ölçeği'nden elde edilen puanların cinsiyete göre anlamlı farklılık gösterip göstermediğini belirlemek amaciyla ilişkisiz örneklemler $t$ testi kullanılmıştır. Öğrencilerin başarı testi puanları ile matematik not ortalamaları ve matematiksel dile ilişkin görüşleri arasında ilişki olup olmadığını belirlemek için de Pearson Korelasyon Katsayısı kullanılmıştır. Öğrencilerin not ortalamalarının hesaplanmasında eğitim-öğretim yılına ait dönem sonu matematik dersi karne notları ele alınmıştır. Ayrıca öğrencilerin başarı testi puanlarının, not ortalamalarının ve matematiksel dile ilişkin görüşlerinin normal dağılıma uyup uymadığında ise skewness-kurtosis sonuçları dikkate alınmıştır.

\section{Bulgular}

$\mathrm{Bu}$ bölümde araştırmanın belirlenen alt problemlerine ilişkin çözümlemeler sonucunda elde edilen bulgular ve bu bulgularla ilgili yorumlara yer verilmiştir. Her bir alt probleme ait, istatistiksel işlemler sonucunda elde edilen analiz bulguları ve yorumlar aşağıda belirtilmiş̧ir.

\section{Birinci alt probleme ilişkin bulgular}


Araştırmanın birinci alt probleminde "Sekizinci sınıf öğrencilerinin kareköklü ifadeler konusundaki matematiksel dili kullanabilme düzeyleri nedir?" sorusuna yanıt aranmaya çalışılmış. Sekizinci sınıf öğrencilerinin kareköklü ifadeler Başarı Testi'nden elde ettikleri puanlar ve sorulara verdikleri yanıtlar incelenmiştir. Başarı testinden elde edilen puanların ortalaması ve standart sapma değerleri ise Tablo 4'de belirtilmiştir.

Tablo 4.

Kareköklü ifadeler başarı Testi Puanlarına Ait Ortalama ve Standart Sapma Değeri

\begin{tabular}{lllcll} 
& $\mathrm{N}$ & Ortalama & s.s. & Minimum & Maksimum \\
\hline $\begin{array}{l}\text { Matematiksel Dili Kullanabilme } \\
\text { Düzeyleri }\end{array}$ & 114 & 0.614 & 0.484 & 0.00 & 1.68
\end{tabular}
Düzeyleri

Tablo 4 incelendiğinde çalışmaya katılmış olan 114 sekizinci sınıf öğrencisine uygulanmış olan kareköklü ifadeler başarı testinden elde etmiş oldukları puan ortalamalarının $X=0.614$ olduğu görülmektedir. $\mathrm{Bu}$ bağlamda öğrencilerin elde ettikleri puan ortalaması değerlendirildiğinde uygulamaya katılan öğrencilerin kareköklü ifadeler konusunda eksikliklerinin olduğu ve bunların geliştirilmesi gerektiği görülmüştür.

\section{İkinci alt probleme ilişsin bulgular}

Araştırmanın ikinci alt probleminde öğrencilerin kareköklü ifadeler konusundaki matematiksel dili kullanabilme düzeyleri ile matematik not ortalamaları arasında ilişkinin var olup olmadığının belirlenmesine yönelik olup elde edilen sonuçlar tablo 5'teki korelasyon tablosunda belirtilmiştir.

Tablo 5 .

Sekizinci Sınıf Öğrencilerinin Matematik Not Ortalamaları İle Matematiksel Alan Dili Kullanabilme Düzeyleri Arasındaki İlişkiyi Belirten Korelasyon Sonuçları

\begin{tabular}{llcc}
\hline Değişkenler & Matematik & $\begin{array}{c}\text { Matematiksel Dili Kullanabilme } \\
\text { Düzeyleri }\end{array}$ \\
\hline Matematik Notu & $\begin{array}{l}\text { Pearson } \\
\text { Korelasyon }\end{array}$ & 1 & $0.620^{* *}$ \\
& $\mathrm{P}$ & & 0.000 \\
& $\mathrm{~N}$ & 114 & 114 \\
\hline Matematiksel Dili & Pearson & $0.620^{* *}$ & 1 \\
Kullanabilme Düzeyleri & korelasyon & & \\
& $\mathrm{P}$ & 0.000 & 114 \\
\hline
\end{tabular}

Tablo 5 incelendiğinde; öğrencilerin matematiksel dili kullanabilme düzeyleri ile matematik başarıları arasında orta düzeyde, pozitif ve anlamlı bir ilişkinin olduğu görülmektedir $(r=0.620$; $\mathrm{p}<0.001$ ). Buna göre matematik başarıları arttıkça matematiksel dili anlayabilme ve kullanabilme düzeylerinin de arttığı söylenebilir.

\section{Üçüncü alt probleme ilişkin bulgular}

Araştırmanın üçüncü alt probleminde sekizinci sınıf öğrencilerinin kareköklü ifadeler konusundaki matematiksel dili kullanabilme düzeyleri onların cinsiyetlerine göre istatistiksel olarak anlamlı bir fark gösterip göstermediği belirlenmek istenmiştir. Sekizinci sınıf öğrencilerinin kareköklü ifadeler konusundaki matematiksel dili kullanabilme düzeylerinin onların cinsiyetlerine göre önemli bir farklılık gösterip göstermediğini incelemek amacıyla yapılan t-testi sonuçları Tablo 6'da verilmiştir. 
Tablo 6.

Cinsiyete Göre Öğrencilerin Matematiksel Dili Kullanabilme Düzeyleri t Testi Sonuçları

\begin{tabular}{llllccc}
\hline Cinsiyet & $\mathrm{N}$ & $\mathrm{X}$ & $\mathrm{S} . \mathrm{S}$ & $\mathrm{sd}$ & $\mathrm{t}$ & $\mathrm{p}$ \\
\hline Kadın & 74 & 0.6087 & 0.477 & 112 & -0.170 & 0.865 \\
Erkek & 40 & 0.6250 & 0.502 & & & \\
\hline
\end{tabular}

$* \mathrm{p}<0.05$ fark anlaml

Yapılan t-testi sonucunda öğrencilerin matematiksel dili kullanabilme düzeylerinin cinsiyetlerine göre önemli bir farkl11ı göstermediği bulgusuna ulaşılmıştır $(t=-0.170 ; p=0.865>0.05)$.

\section{Dördüncü alt probleme ilişkin bulgular}

Araştırmanın dördüncü alt probleminde sekizinci sınıf öğrencilerinin matematiksel dil kullanımına ilişskin görüşleri nedir? Sorusuna yanıt aranmaya çalışılıış bu bağlamda sekizinci sınıf öğrencilerinin Matematiksel Dil Ölçeğine verdikleri cevapların puan ortalamaları ve standart sapma değerleri Tablo 7'de gösterilmiştir.

Tablo 7.

Öğrencilerin Matematiksel Dil Ölçeğinden Elde Ettikleri Puan Ortalamaları ve Standart Sapma Değerleri

\begin{tabular}{lll}
\hline & $X$ & s.s. \\
\hline Problem Çözme & 3.7558 & 0.74542 \\
Görselleştirme & 4.0877 & 0.85996 \\
Kavram Kullanma & 4.1842 & 0.90511 \\
Yazılı Ödev & 3.7259 & 0.88371 \\
Sembolik Anlatım & 4.0468 & 0.90652 \\
Genel & 3.9411 & 0.70352 \\
& & \\
\hline
\end{tabular}

Öğrencilerin matematiksel dil kullanıma ilişkin görüşlerinin puan ortalamaları incelendiğinde olumlu görüşe sahip oldukları görülmektedir $(X$ genel=3.9411). Ayrıca öğrencilerin görüşlerinin puan ortalamaları matematiksel dil ölçeğinin alt boyutları açısından ayrı ayrı incelendiğinde de aynı şekilde olumlu görüsşe sahip oldukları sonucuna ulaşılmıştır ( $X$ problem çözme $=3.7558 ; X$ sembolik anlatım=4.0468; $X$ yazılı ödev=3.7259; $X$ görselleştirme $=4.0877 ; X$ kavram kullanımı=4.1842).

\section{Beşinci alt probleme ilişkin bulgular}

Araştırmanın beşinci alt probleminde sekizinci sınıf öğrencilerinin kareköklü ifadeler konusundaki matematiksel dili kullanabilme düzeyleri ile matematiksel dil kullanımına yönelik görüşleri arasındaki ilişki incelenmiş alt probleme yönelik öncelikle matematiksel dil ölçeğinden elde ettikleri puanların normal dağılıma uyup uymadığı incelenmiştir. Verilerin normal dağılıma uyup uymadıklarını gösteren Skewness-Kurtosis analiz sonuçlarına göre, öğrencilerin matematiksel dil ölçeğinden ettikleri puanların normal dağılıma uymadığı görülmüştür bu nedenle normal dağılım göstermesi için $\log 10$ dönüşümü ile normal dağ 1 lıma çevrilmiştir (Ç.K=0.468, $-1<C ̧ . K<1$ ). Normal dağılıma dönüştürüldükten sonra parametrik testler kullanılmıştır.Matematiksel dil ölçeğinden elde edilen puanlara ait istatistiksel hesaplamalarda parametrik testler kullanılmıştır. Öğrencilerin kareköklü ifadeler konusundaki matematiksel dili kullanabilme düzeyleri ile matematiksel dil kullanımına ilişkin görüşleri arasında önemli bir ilişki olup olmadığı Pearson Korelasyon Katsayısı ile belirlenmiş olup sonuçları tablo 8'de gösterilmiştir. 
Tablo 8.

Öğrencilerin Kareköklü İfadeler Konusundaki Matematiksel Dili Kullanabilme Düzeyleri İle Matematiksel Dil Kullanıma İlişkin Görüşleri Arasındaki Pearson Korelasyon Katsayısı Değerleri

\begin{tabular}{llcc}
\hline & & $\begin{array}{l}\text { Matematiksel Dil } \\
\text { Kullanımına İlişkin } \\
\text { Görüşleri }\end{array}$ & $\begin{array}{l}\text { Matematiksel Dili } \\
\text { Kullanabilme Düzeyleri }\end{array}$ \\
\hline Matematiksel Dil & Pearson & 1 & -0.158 \\
Kullanımına ̇̇lişkin & Korelasyon & & 0.094 \\
Görüşleri & $\mathrm{P}$ & 114 & 114 \\
& $\mathrm{~N}$ & -0.158 & 1 \\
\hline Matematiksel Dili & Pearson & & \\
Kullanabilme Düzeyleri & Korelasyon & 0.094 & 114 \\
& $\mathrm{P}$ & 114 & \\
& $\mathrm{~N}$ & & \\
\hline
\end{tabular}

Tablo 8 incelendiğinde; öğrencilerin matematiksel dili kullanabilme düzeyleri ile matematiksel dil kullanımına ilişkin görüşleri arasında düşük düzeyde, negatif ve anlamlı bir ilişkinin olmadığ görülmektedir $(\mathrm{r}=-0.158 ; \mathrm{p}>0.05)$.

\section{Altıncı alt probleme ilişkin bulgular}

Araştırmanın altınc1 alt probleminde sekizinci sınıf öğrencilerinin matematiksel dil kullanımına ilişkin görüşleri ile akademik matematik başarısı arasında ilişkinin olup olmadı̆̆ araştırılmış bu doğrultuda öğrencilerin görüşleri ile matematik başarıları arasında önemli bir ilişki olup olmadığı Pearson Korelasyon Katsayısı ile belirlenmiş olup sonuçları Tablo 9'da gösterilmiştir.

Tablo 9.

Öğrencilerin Matematiksel Dil Kullanımına İlişkin Görüşleri ile Matematik Başarıları Arasındaki Pearson Korelasyon Katsayısı Değerleri

\begin{tabular}{cccc}
\hline & & $\begin{array}{c}\text { Matematiksel Dil Kullanımına } \\
\text { İlişkin Görüşleri }\end{array}$ & $\begin{array}{c}\text { matematik not } \\
\text { ortalaması }\end{array}$ \\
\hline $\begin{array}{c}\text { Matematiksel Dil Kullanımına } \\
\text { İlişkin Görüşleri }\end{array}$ & $\begin{array}{c}\text { Pearson } \\
\text { korelasyon }\end{array}$ & 1 & -0.101 \\
& $\mathrm{P}$ & & \\
& $\mathrm{N}$ & 114 & 0.287 \\
& Pearson & -0.101 & 114 \\
\hline matematik not ortalaması & korelasyon & & 1 \\
& $\mathrm{P}$ & 0.287 & 114 \\
\hline
\end{tabular}

Tablo 9'a göre, öğrencilerin matematiksel dil kullanımına ilişkin görüşleri ile matematik başarıları arasında düşük düzeyde, negatif ve anlamlı bir ilişkinin olmadığ 1 görülmektedir $(\mathrm{r}=-0.101$; $\mathrm{p}>0.05)$.

Yedinci alt probleme ilişkin bulgular

Araştırmanın yedinci alt probleminde sekizinci sınıf öğrencilerinin Matematiksel dil kullanımına ilişkin görüşleri ile cinsiyet değişkeni açısından anlamlı bir farkın gösterip göstermediği incelenmiş bu amaçla yapılan t-testi sonuçları Tablo 10'da verilmiştir. 
Tablo 10.

Cinsiyete Göre Öğrencilerin Matematiksel Dil Kullanımına Yönelik Görüşlerine ait t Testi Sonuçları

\begin{tabular}{ccccccc}
\hline Cinsiyet & $\mathrm{N}$ & $\mathrm{X}$ & $\mathrm{S} . \mathrm{S}$ & $\mathrm{sd}$ & $\mathrm{t}$ & $\mathrm{p}$ \\
\hline Kadın & 74 & 0.2424 & 0.14322 & 112 & -1.626 & 0.107 \\
Erkek & 40 & 0.2878 & 0.14132 & & & \\
\hline
\end{tabular}

$* \mathrm{p}<0.05$ fark anlaml

Tablo 10 incelendiğinde yapılan t-testi sonucuna göre öğrencilerin matematiksel dil kullanımına yönelik görüşlerinin cinsiyete göre anlamlı farklılık göstermediği bulgusuna ulaşılmıştır $(\mathrm{t}=-1.626 ; \mathrm{p}=0.107>0.05),(X \mathrm{kız}=0.2424, X$ erkek=0.2878 $)$. Ayrıca ögrencilerin matematiksel dil ölçeğinin alt faktörlerine ait görüşlerinin cinsiyete göre anlamlı farklılık gösterip göstermediği incelenmiş ve elde edilen veriler Tablo 11'de gösterilmiştir.

Tablo 11.

Cinsiyete Göre Öğrencilerin Matematiksel Dil Ölçeğinin Alt Faktörlerine Yönelik Görüşlerine Ait t Testi Sonuçları

\begin{tabular}{lccccccl}
\hline & Cinsiyet & $\mathrm{N}$ & $\mathrm{X}$ & $\mathrm{S} . \mathrm{S}$ & $\mathrm{Sd}$ & $\mathrm{T}$ & $\mathrm{P}$ \\
\hline Görselleştirme & Kadın & 74 & 0.2367 & 0.17587 & 112 & -0.594 & 0.554 \\
& Erkek & 40 & 0.2575 & 0.18307 & & & \\
\hline Sembolik Anlatım & Kadın & 74 & 0.2360 & 0.19542 & 112 & -1.134 & 0.260 \\
& Erkek & 40 & 0.2756 & 0.16704 & & & \\
\hline Kavram Kullanma & Kadın & 74 & 0.2032 & 0.18185 & 112 & -1.043 & 0.299 \\
& Erkek & 40 & 0.2412 & 0.19287 & & & \\
\hline Yazılı Ödev & Kadın & 74 & 3.7973 & 0.83140 & 112 & 1.176 & 0.242 \\
& Erkek & 40 & 3.5938 & 0.97021 & & & \\
\hline Problem Çözme & Kadın & 74 & 3.8604 & 0.73198 & 112 & 2.065 & 0.041 \\
& Erkek & 40 & 3.5625 & 0.74026 & & & \\
\hline
\end{tabular}

$* \mathrm{p}<0.05$ fark anlaml 1

Tablo 11 incelendiğinde matematiksel dil ölçeğinin problem çözme alt faktöründe ( $\mathrm{t}=; 2.065$ $\mathrm{p}=0.041<0.05$ ), öğrenci görüşlerinin cinsiyete göre anlamlı bir fark gösterdiği görülmektedir. Buna göre ortalamalar incelendiğinde k1z öğrencilerin problem çözmeye ilişkin görüşlerinin erkek öğrencilere göre daha olumlu olduğu görülmüştür $(X \mathrm{k} 1 z=3.8604 ; X$ erkek=3.5625). Sembolik anlatım alt faktöründe ( $\mathrm{t}=-1.134 ; \mathrm{p}=0.260>0.05)$ ve kavram kullanımı alt faktöründe $(\mathrm{t}=-1.043 ; \mathrm{p}=0.299>$ 0.05) öğrenci görüşlerinin cinsiyete göre anlamlı bir farklılık göstermediği görülmektedir. Aynı şekilde yazılı ödev alt faktöründe ise öğrenci görüşlerinin cinsiyete göre anlamlı farklılık göstermediği bulgusuna ulaş1lmıştır $(\mathrm{t}=1.176 ; \mathrm{p}=0.242>0.05)$. Benzer şekilde görselleştirme alt faktörü incelendiğinde öğrenci görüşlerinin cinsiyete göre anlamlı farkl1lı göstermediğ görülmektedir $(\mathrm{t}=$ $0.594 ; \mathrm{p}=0.554>0.05)$.

\section{Tartıșma, Sonuç ve Öneriler}

Araştırmada ortaokul sekizinci sınıf öğrencilerinin kareköklü ifadeler konusundaki alan dilini kullanabilme düzeylerini ve matematiksel dil kullanımına ilişkin görüşlerini belirlemek ve bunların bazı değişkenler açısından nicel olarak incelenmesi amaçlanmıştır. $\mathrm{Bu}$ bölümde araştırmanın örneklemini oluşturan 114 öğrenciden elde edilmiş veriler doğrultusunda farklı değişkenler bakımından elde edilen bulgular tartışılacaktır. Literatür incelendiğinde matematiksel dil ölçeğiyle ilgili önceden yapılmış çalışmaların olduğu görülürken ( Akarsu, 2013; Aydın ve Yeşiyurt, 2007 Çalıkoğlu Bali, 2002; Güzel ve Yılmaz, 2020), kareköklü ifadeler konusundaki alan dilini inceleyen herhangi bir çalışmaya rastlanılmamıştır. Bu bağlamda kareköklü ifadeler konusuna yönelik yapılmış bu çalışmanın literatüre katkı sağlayacağı umulmaktadır. 
Sekizinci sınıf öğrencilerinin kareköklü ifadeler konusundaki matematiksel dili kullanabilme düzeyleri incelendiğinde elde edilen sonuçlara göre öğrencilerin kareköklü ifadeler konusunda eksiklerinin olduğu ve bunların geliştirilmesi gerektiği $(X=0.6144)$ sonucuna ulaşılmıştır. Kareköklü ifadeler başarı testinin sonuçlarına göre öğrencilerin bir çoğunun kareköklü ifadeler konusunda var olan temel özellikleri ve genel kuralları içeren soruların çözümünde hata yaptıkları görülmüştür. Öğrenciler kareköklü ifadelerde dört işlem içeren sorularda toplama ve çıkarma işleminin özelliklerini çarpma işleminin kurallarına genelledikleri dolayısıyla başarı testinde yetersiz olmalarının bir nedeninin ise bilgi eksikliği ve yanlış genellemelerden kaynaklandığı düşünülmektedir. Öğrencilerden $\sqrt{36} \cdot \sqrt{x}=72$ matematiksel denklemine uygun bir problem cümlesi oluşturmaları istendiğinde öğrencilerin büyük çoğunluğu bilinmeyenin değerini bulduğu ama problem cümlesi kurmaları istediğinde ise daha çok verilen matematiksel ifadenin okunuşunu yazdıkları görülmüştür. Literatür incelendiğinde ilköğretim matematik öğretmen adayları üzerine yapılan çalışma sonuçları adayların kullanmış oldukları matematiksel ifadelerin doğru olup olmadığına bakılmaksızın, yalnızca alan dilini uygun ve yeterli bir biçimde kullanan adaylar örneklemin sadece \%36'l1k kısmını oluşturduğu aynı şekilde alan dilini tamamen yanlış bir şekilde kullananlar \%45'ini oluşturmuştur. Bu bağlamda araştırmanın sonucuna göre öğretmen adaylarının matematiksel alan dilini yeterli şekilde kullanmadıkları sonucuna ulaşılırken (Yeşildere, 2007), Yılmaz ve Türkmen (2019)'nin geometri öğrenme alanına çalışmasında öğrencilerin matematiksel dili anlayabilme ve kullanabilme düzeyleri incelenmiş ve bu doğrultuda öğrencilerin sadece \%36.7'sinin matematiksel dil kullanım düzeyinin düşük olduğu, \% 52.3'ünün matematiksel dil kullanım düzeyinin orta düzeyde olduğu, \% 11.1'inin matematiksel dil kullanım düzeyinin yüksek düzeyde olduğu görülmüştür bu sonuçlar da göstermektedir ki çoğunluğunun orta seviyede dağıldığg çok azının alan dili kullanım düzeylerinin yüksek olduğu görülmüştür. Başka bir çalışmada İlköğretim matematik öğretmen adaylarının Analitik Geometri Alan Bilgisi Beceri Testinden elde ettikleri puanlarının ortalaması göz önüne alındığında adayların analitik geometri alan dili başarılarının düşük olmadığı tespit edilmiştir (Nur Pazarbaşı, 2015). Başka çalışmada ise alan dilinden ziyade köklü ifadeler ile ilgili Şenay (2002)'ın çalışmasında öğrencilerin sayılar ve işlemler öğrenme alanına yönelik yapmış olduğu çalışmanın sonuçları incelendiğinde köklü sayıları tanıma ve işlem yapmada zorlandıkları ve ayrıca kavram yanılgılarına sahip oldukları görülmüsstür ayrıca öğrencilerin konuya yönelik kuralların ve kavramlar konusunda yetersiz oldukları ve doğal olarak kural ve kavramları birbirine karıştırdıkları saptanmıştır ki bu çalışmanın sonuçları da üzerinde çalışma yürütülen çalışmanın sonuçları ile paralellik gösterdiği görülmektedir çünkü öğrencilerin vermiş oldukları yanıtlar incelendiğinde genel olarak aşırı genelleme yaptıkları ve köklü sayılarla dört işlem gerektiren kurallarda yetersiz oldukları görülmüștür. Cengiz (2006)'in Reel Sayıların Öğretiminde Bir Kısım Ortaöğretim Öğrencilerinin Yanılgıları Ve Yanlışlar Üzerine Bir Çalışma başlıklı çalışmasının sonuçları incelendiğinde öğrencilerin köklü ifadelerde yanılgılara sahip oldukları ve konunun içeriğinde yer alan kuralları birbirlerine karıştırdıkları görülmektedir bu bulgularda çalışmaya paralel sonuçlara ulaştırmaktadır ancak çalışmanın lise birinci sınıf öğrencileri ile yürütülmüş olması ve ayrıca sekizinci sınıfta yer almayan bazı kazanımlarında yer almaması bu sonucu etkilemiş olduğu söylenebilir. Benzer şekilde öğrencilerin kareköklü ifadeler alan dili başarı testinde Öğrenci yanıtları incelendiğinde öğrencilerin matematiksel işlem gereken sorularda karekök içindeki sayının da negatif olabileceğini belirttikleri görülmüş bu da Orhun (1998)'un, yapmış olduğu çalışmada her zaman pozitif sayıların karekökleri alındığında tanımlı olması gerektiği ve $\sqrt{a^{2}}=$ a eşitliğinin sayının negatif olması durumunda sağlanamayacağını fark edemedikleri görüldüğü fikrini desteklemektedir. Bir başka çalışma Baltalı (2018)'nın sayılar ve işlemlerle ilgili öğrenci hatalarının incelenmesi başlıklı yüksek lisans tezinin sonuçları incelendiğinde sekizinci sınıf öğrencilerinin uygulanan tanı testinde köklü sayılarla ilgili bölümde sıralama, yoğunluk ve işlem olarak incelenmiş ve elde edilen sonuçlara göre öğrencilerin, tanı testindeki köklü sayılarla ilgili maddelere göre orta düzey başarılı oldukları, yoğunluk ve işlem bölümündeki sorularında katılımcıların yarısının başarılı olduğu köklü sayılarda sıralama ile ilgili sorulardaki başarılarının ise düşük olduğu görülmüştür. Bu araştırmanın sonuçları da göstermektedir ki öğrencilerin köklü sayılar konusunda işlem yapmakta yetersiz oldukları ve zorlandıkları ve konuya yönelik kurallara yeterince hakim olmadıkları ve bu da hatalara sebep olduğu sonucuyla paralellik göstermektedir. Literatürde yalnızca öğrencilerin matematiksel dil kullanımı üzerine yapılan çalışmalara rastlanmadığı ayrıca öğretmen adayları üzerine yapılan çalışmaların da olduğu görülmektedir. 
Emre, Yazgan-Sağ, Gülkılık ve Argün (2017)'ün" Matematik Öğretmen Adaylarının Matematiksel Dil Kullanımları" başlıklı çalışmasında katılımcılar kavramları ifade ederken daha çok sözel dili tercih ettikleri görülürken sembolik dil kullanmada yetersiz oldukları görülmüştür. Sonuçlar incelendiğinde öğretmenlerin yetersiz olmaları öğrencilerin alan dilini kullanma konusunda yetersiz olmasının bir nedeni olarak düşünülebilir. Ünal (2013)'`n yedinci sınıf öğrencileriyle yapmış olduğu geometri öğrenme alanına yönelik sahip oldukları matematiksel dil kullanım düzeyleri incelendiğinde bu düzeyin orta seviyede olduğu görülmüştür. Farklı bir çalışmada altıncı ve yedinci sınıf öğrencilerinin performans görevlerinden yararlanarak matematiksel dili kullanabilme düzeyinin belirlendiği çalışmada öğrencilerin kavramları kullanmakta zorlandıkları, dolayısıyla matematiksel dili kullanmakta zorluk yaşadıkları görülmüştür (Yüzerler, 2013). Figen( 2016)'in çalışmasında ise altıncı ve yedinci sınıf öğrencileriyle gerçekleştirilen çalışmada kesirler konusunda matematiksel dili anlayabilme ve kullanabilme düzeylerinin sözel, sembolik ve görsel olacak biçimde üç alt boyutta incelenen çalışmada matematiksel dil kullanım düzeyinin en yüksek olduğu boyutun görsel dil olduğu ancak en düşük puanın ise sözel dil olduğu tespit edilmiştir (Yıldız, 2016). Güzel ve Yılmaz (2020)'1n çalışmasında ise öğrencilerin üslü ifadeler başarı testine vermiş oldukları cevaplara göre elde edilen puan ortalaması değerlendirildiğinde uygulamaya katılan öğrencilerin üslü ifadeler konusunda matematiksel dili anlayabilme ve kullanabilme düzeylerinin orta düzeyde olduğu görülmüş ayrıca matematiksel dil kullanım düzeyi düşük, orta ve yüksek seviye olacak şekilde kategorilendirildiğinde \%34'ünün matematiksel dil kullanım düzeyinin düşük olduğu, \% 48'inin orta düzeyde olduğu, \% 18' inin yüksek düzeyde olduğu anlaşılmaktadır. Akarsu (2013), Çakmak (2013), Ünal (2013), Yüzerler (2013), Yeşil (2015) ve Yıldız (2016) matematiksel dil alanında yaptıkları araştırmalarda, öğrencilerin matematiksel dil kullanım becerilerinin yeterli düzeyde olmadığı sonucuna ulaşılmıştır. Çalışmaların sonuçları incelendiğinde köklü ifadeler konusunda alan dilini inceleyen bir çalışmaya rastlanmamış olsa da genel olarak matematiksel alan dilini anlayabilme ve kullanabilme konusunda yetersiz olunduğu aynı zamanda bu yetersizliğin bir başka nedeni ise hem öğreticilerin hem de öğrencilerin yeterli bir konu alan bilgisine sahip olmadıkları etkili olduğu söylenebilir.

Araştırmanın ikinci alt probleminin sonucu olarak öğrencilerin kareköklü ifadeler konusundaki matematiksel dili kullanabilme düzeyleri ile matematik karne not ortalaması arasındaki ilişki doğrultusunda elde edilen sonuçlar incelendiğinde öğrencilerin matematiksel dili kullanabilme düzeyleri ile matematik başarıları arasında orta düzeyde, pozitif ve anlamlı bir ilişkinin olduğu görülmektedir $(\mathrm{r}=0.620 ; \mathrm{p}<0.001)$. Buna göre öğrencilerin matematik başarıları arttıkça matematiksel dili anlayabilme ve kullanabilme düzeylerinin arttı̆̆ söylenebilir. Güzel ve Yılmaz (2020)'1n sekizinci sınıf öğrencilerinin üslü ifadeler konusundaki matematiksel dil kullanımı ve dile ilişkin görüşleri başlıklı araştırmasının sonuçlarına göre öğrencilerin matematiksel dili anlayabilme ve kullanabilme düzeyleri ile matematik başarıları arasında orta düzeyde, pozitif ve anlamlı bir ilişkinin olduğu görülmüştür ( $r=, 651 ; \mathrm{p}<.001)$. Dolayısıyla öğrencilerin matematik başarıları arttıkça matematiksel dili anlayabilme ve kullanabilme düzeylerinin arttığı söylenebilir. Bu da göstermektedir ki öğrencilerin dönem sonu karne not ortalamaları onların başarı testi puanlarını desteklemektedir. $\mathrm{Bu}$ çalışmayı destekleyecek şekilde Yılmaz ve Türkmen (2019) yedinci sınıf öğrencileri ile yaptığı çalışmada öğrencilerin matematik başarıları ile geometri öğrenme alanına yönelik gerçekleştirmiş oldukları matematiksel dil kullanımı ölçeği verilerine göre öğrencilerin matematiksel dil kullanımı, matematik başarılarına göre farklı1ık göstermekte ve ayrıca $(F(4-194)=43,154 \mathrm{p}<0.05)$ öğrencilerin matematiksel dil kullanım düzeylerinin sınırlı ve yetersiz olduğu görülmüştür. Örneklemi oluşturan öğrencilerin çoğu orta seviyede yer alırken en az öğrenci ise yüksek düzeyde yer almaktadır. Başka bir çalışmada geometri öğrenme alanına yönelik yapılan çalışmada öğrencilerin matematiksel dili kullanma sıklıkları ile matematiksel dili doğru kullanma becerileri arasında ilişki olduğu sonucuna ulaşılmıştır (Açıl ve Zeybek, 2017). Bir başka çalışmada ise altıncı ve yedinci sınıf öğrencileriyle gerçekleştirilen çalışmada kesirler konusunda matematiksel dili anlayabilme ve kullanabilme düzeyleri ile matematik başarıları arasında pozitif ve anlamlı ( $r=0.70)$ bir ilişkinin olduğu bilgisine ulaşılmıştır (Yıldız, 2016).

Araştırmanın üçüncü alt probleminde öğrencilerinin kareköklü ifadeler konusundaki matematiksel dili anlayabilme ve kullanabilme düzeyleri onların cinsiyetlerine göre istatistiksel olarak anlamlı bir fark gösterip göstermediğine yönelik sonuçlar incelendiğinde yapılan $\mathrm{t}$-testi sonucunda öğrencilerin matematiksel dili anlayabilme ve kullanabilme düzeylerinin cinsiyetlerine 
göre önemli bir farkl1lık göstermediği bulgusuna ulaşılmıştır $(\mathrm{t}=-0.170 ; \mathrm{p}=0.865>0.05) . \mathrm{Bu}$ da göstermektedir ki cinsiyetin kız veya erkek olması kareköklü ifadelere yönelik elde edeceği başarı puanında bir değişim meydana getirmemektedir. Literatür incelendiğinde benzer şekilde öğrencilerin kullanmış oldukları matematiksel dilin düzeyi cinsiyet değişkeni açısından bir fark göstermediği ve grupların dil kullanım düzeylerinin orta düzeyde $(17 \leq X \leq 33$; orta düzey; $X \mathrm{k} 1 \mathrm{z}=21.52 ; X$ erkek=19.8) olduğu sonucuna ulaşılırken (Yılmaz ve Türkmen, 2019), bu çalışmada ( $X$ kız $=0.6087 ; X$ erkek=0.6250) grupların matematiksel alan dili kullanım düzeylerinin yetersiz olduğu ve geliştirilmesi gerektiği bulgusuna ulaşılmıştır. Araştırmaya paralel olan bir başka çalışma yedinci sınıf öğrencileriyle yapılmış olup matematiksel dil kullanım düzeylerinin belirlenmesi hedeflenmiş ve geometri öğrenme alanına yönelik sahip oldukları matematiksel dil kullanım düzeylerinin cinsiyet değişkenine göre farklılık göstermediği ve böylece cinsiyetin matematiksel dil kullanımı üzerinde etkisinin olmadığını göstermektedir (Ünal, 2013).

Araştırmanın dördüncü alt probleminde öğrencilerin matematiksel dil ölçeğine vermiş oldukları yanıtlar incelendiğinde öğrencilerin matematiksel dil kullanımına yönelik olumlu bir görüşe sahip oldukları görülmüştür. Ayrıca ölçeğin alt boyutları tek tek incelendiğinde problem çözme, sembolik anlatım, yazılı ödev, görselleştirme ve kavram kullanımı doğrultusunda görüşlerinin olumlu olduğu sonucuna ulaşılmıştır $(X$ genel $=3.9411) ;(X$ problem çözme $=3.7558 ; X$ sembolik anlatım=4.0468; $X$ yazılı ödev $=3.7259 ; X$ görselleştirme $=4.0877 ; X$ kavram kullanımı $=4.1842)$. Literatür incelendiğinde Çalıkoğlu Bali (2002)'nin geliştirdiği ölçeğin bulgularında matematik derslerine yönelik öğretimlerin gerçekleştirilmesinde yazılı ve sözlü anlatımlara ağırlık verilmesi gerektiği ve önemli görüldüğü sınıf içinde gerçekleşen konuşmalarda öğrencilerin görüşlerini belirtirken uygun matematiksel kavramları, terimleri ve sembolleri kullanmalarına imkan verilmesi gerektiği sonucuna ulaşılmıştır. Nur Pazarbaş1 ( 2015)'nın öğretmen adayları ile yapmış olduğu çalışmanın sonuçlarına göre Analitik Geometri Alan Diline Yönelik Tutumlarının olumsuz olmadığ 1 söylenebilir. Araştırmanın sonuçlarını destekleyen Güzel ve Yılmaz (2020)'ın sekizinci sınıf öğrencilerinin matematiksel dil kullanımına ilişkin görüşünü inceleyen çalışmada, öğrencilerin matematiksel dil kullanıma ilişkin görüşlerinin puan ortalamaları incelendiğinde matematiksel dilin kullanımına yönelik olumlu görüşe sahip oldukları görülmektedir $\left(\overline{\mathrm{x}}_{\text {genel }}=4.1348\right)$ ayrıca öğrencilerin görüşlerinin puan ortalamaları matematiksel dil ölçeğin alt boyutları açısından ayrı ayrı incelendiğinde görselleştirme, sembolik anlatım ve kavram kullanımına dair tamamen olumlu görüşe sahip oldukları görülürken $\left(\overline{\mathrm{x}}_{\text {sembolik anlatım }}=4.2400 ; \bar{x}_{\text {görselleştirme }}=4.2600 ; \bar{x}_{\text {kavram }}\right.$ kullanımı $=4$.2040) dil ölçeğinin diğer boyutları olan yazılı ödev ve problem çözmeye yönelik görüşlerinin olumlu olduğu tespit edilmiştir $\left(\bar{x}_{\text {yazılıödev }}=4.0100 ; \bar{x}_{\text {problem çözme }}=4.0556\right)$.

Araştırmanın beşinci alt probleminde öğrencilerinin kareköklü ifadeler konusundaki matematiksel alan dili kullanabilme düzeyleri ile matematiksel dil kullanımına ilişkin görüşleri arasında anlamlı bir ilişkinin olup olmadığı incelendiğinde öğrencilerin matematiksel dili kullanabilme düzeyleri ile matematiksel dil kullanımına ilişkin görüşleri arasında düşük düzeyde, negatif ve anlamlı bir ilişkinin olmadığ $1(\mathrm{r}=-0.158 ; \mathrm{p}>0.05)$ görülmüştür. ilişkiyi inceleyen farklı bir çalışmada ise yedinci sınıf öğrencilerinin Cebir Öğrenme Alanında Matematiksel Dili Anlayabilme ve Kullanabilme ve Düzeyleri ile Matematiksel Dil Kullanımına İlişkin Görüşleri arasındaki ilişki incelenmiş elde edilen verilere göre düşük düzeyde, pozitif ve anlamlı bir ilişkinin olduğu görülmektedir $(\mathrm{r}=0.220$; $\mathrm{p}<0.05)$ (Akarsu, 2013). literatür incelendiğinde geometri öğrenme alanına yönelik matematiksel dil kullanabilme düzeyi ile matematiksel dil ölçeğinin boyutlarından olan sözlü ifade, sembolik anlatım, yazılı ifade ve ödev alt boyutları açısından incelendiğinde bir farklılık görülmediği ancak diğer boyutlar olan problem oluşturma, kavram oluşumu ve şekle dönüştürme alt boyutları için ise bu şekilde olmadığı tam tersine matematiksel dil kullanım düzeylerine göre farklılık olduğu görülmüştür (Yılmaz ve Türkmen, 2019). Nur Pazarbaşı (2015)'nın öğretmen adayları ile yapmış olduğu çalışmasında analitik geometri alan dili başarıları ile analitik geometri alan diline yönelik tutumları arasında ilişkinin görülmediği ( $\mathrm{r}=0.079 ; \mathrm{p}>0.05)$ ilişkinin anlamlı olmadığg saptanmıştır. İncelenen çalışmalarda Alan dilini anlayabilme ve kullanabilme düzeyleri ile buna yönelik görüşlerini inceleyen farklı matematik konularına yönelik çalışmalara rastlanmasına rağmen köklü veya kareköklü ifadeleri içeren benzer bir çalışmaya ulaşılamamıştır. 
Araştırmanın altıncı alt probleminde öğrencilerin matematiksel dil kullanımına ilişkin görüşleri ile akademik matematik başarısı yani matematik karne not ortalaması arasında anlamlı bir ilişkinin olup olmadığına yanıt aranmaya çalışılmış ve elde edilen sonuçlar incelendiğinde öğrencilerin matematiksel dil kullanımına ilişkin görüşleri ile matematik başarıları arasında düşük düzeyde, negatif ve anlamlı bir ilişkinin olmadığı görülmektedir ( $\mathrm{r}=-0.101 ; \mathrm{p}>0.05)$. Paralel sonuçlara ulaşılan benzer bir çalışmada da yedinci sınıf öğrencilerinin matematiksel dil kullanımına ilişkin görüşleri ile matematik başarıları arasında düşük düzeyde, pozitif ve anlamlı bir ilişkinin olduğu $(r=0.202 ; p<0.05)$ görülmektedir (Akarsu, 2013).

Araştırmanın yedinci alt probleminde öğrencilerin matematiksel dil kullanımına ilişkin görüşleri ile cinsiyetleri arasında istatistiksel olarak anlamlı bir fark gösterip göstermediği sorgulanmış ve sonuçlar öğrencilerin matematiksel dil kullanımına yönelik görüşlerin cinsiyete göre anlamlı farklılık göstermediği bulgusuna ulaştırmıştır ( $\mathrm{t}=-1.626 ; \mathrm{p}=0.107>0.05),(X \mathrm{k} 1 \mathrm{z}=0.2424, X$ erkek=0.2878 ). Buna göre ortalamalar incelendiğinde kız öğrencilerin problem çözmeye ilişkin görüşlerinin erkek öğrencilere göre daha olumlu olduğu görülmüştür ( $X$ kız=3.8604; $X$ erkek=3.5625). Ancak yedinci sınıf öğrencileri ile yapılan çalışmada öğrencilerin matematiksel dil kullanımına yönelik görüşlerinin cinsiyete göre anlamlı farklılık gösterdiği $(\mathrm{t}=2.450 ; \mathrm{p}=0.015<0.05)$ görülmüştür (Akarsu,2013). Her bir alt boyut içinde incelendiğinde sembolik anlatım alt faktöründe ( $\mathrm{t}=-1.134$; $\mathrm{p}=0.260>0.05)$ ve kavram kullanımı alt faktöründe $(\mathrm{t}=-1.043 ; \mathrm{p}=0.299>0.05)$ öğrenci görüşlerinin cinsiyete göre anlamlı bir farklılık göstermediği görülmektedir. Aynı şekilde yazılı ödev alt faktöründe ise öğrenci görüşlerinin cinsiyete göre anlamlı farklılık göstermediği bulgusuna ulaşılmıştır $(\mathrm{t}=1.176$ $; \mathrm{p}=0.242>0.05)$. Benzer şekilde görselleştirme alt faktörü incelendiğinde öğrenci görüşlerinin cinsiyete göre anlamlı farklılık göstermediği görülmektedir $(\mathrm{t}=-0.594 ; \mathrm{p}=0.554>0.05)$. Ancak Yaman ve Ç.Gülten (2015)' in fen ve matematik öğretmen adaylarının matematik öğretiminde kullanılan dile ilişkin görüşlerinin incelendiği araştırmada matematiksel dil kullanımına ilişkin genel görüşleri ile yazılı anlatım ve yazılı ödevler, problem oluşturma alt boyutlarının cinsiyet değişkenine göre anlamlı bir fark $(\mathrm{U}=1098.500, \mathrm{z}=-2.410, \mathrm{p}<0.05)$ gösterdiği saptanmış ayrıca elde edilen sonuçlara göre kızların dil ölçeğinden almış oldukları toplam puanın erkeklere oranla daha yüksek olduğu görülmüş̧ür. Literatür incelendiğinde ilköğretim matematik öğretmen adaylarının analitik geometri alan dilini kullanma becerileri ve tutumlarının incelendiği çalışmada cinsiyetin analitik geometri alan diline yönelik tutuma bir etkisinin olmadığı $(\mathrm{t}(348)=1.826$; $\mathrm{p}>0.05)$ Cinsiyet değiş̧keninin öğretmen adaylarının analitik geometri alan dili başarısına etkisi olmadığ tespit edilmiştir (Nur Pazarbaşı, 2015).

Alan yazında daha çok köklü ifadeler konusunda var olan kavram yanılgılarını inceleyen çalışmalara rastlanmıştır. Sayılar ve işlemler öğrenme alanı diğer öğrenme alanları ile bağlantılı olan temel konulardan biri olmakta, içeriğinde yer alan konuların tam kavratılmadığı sürece diğer konuların kavratılması mümkün değildir. Bu da bizi kareköklü ifadeler konusunda öğrencilerin hem konu alan bilgilerinin hem de matematiksel dilin kullanıma yönelik derin çalışmalar yapılması gerektiği sonucuna ulaştırmaktadır. Sarmal bir yapıya sahip olan matematik, içeriğinde yer alan konuları arasında bağlantı bulunmaktadır. Yapılan çalışmada görülmektedir ki üslü ifadeler konusunda yetersiz olan öğrenciler kareköklü ifadeler konusunda da hata yaptıkları görülmüştür. Genelde var olan belirli temel kurallarda genellemeler yaptıkları, kavram yanılgılarına ve hatalara düştükleri görülmüştür. Kareköklü ifadeler başarı testine öğrencilerin verdikleri cevaplar incelendiğinde kuralları tam olarak kavrayamadıkları anlaşılmıştır bu nedenle öğreticiler öğrencilere hazır matematiksel kuralları verip ezberlemelerini beklemek yerine, kurallara kendilerinin ulaşmasını sağlayacak şekilde yönlendirmelerde bulunmalıdırlar.

Başarı testinde öğrencilerden, verilen matematiksel ifadeye uygun bir problem cümlesi kurmaları istendiğinde öğrenciler daha çok işleme odaklandıkları ve problem kurmakta yetersiz oldukları tespit edilmiştir. Kurulan problemlerin ise daha çok "Aşağıda yer alan problemi çözünüz “ şeklinde olduğu görülmüştür. Bu nedenle matematik öğretmenleri ders içinde ve ders dişında sadece işlemsel düzeyde ve sonuç odaklı ders işlemek yerine derslerinde öğrencilerin, görüşlerini rahat bir şekilde paylaşmalarını sağlayacak sınıf ortamları oluşturmalı, hem kavramsal boyuta hem de işlemsel boyuta yer verecek şekilde derslerini planlamalıdır. 
Çalıkoğlu Bali (2002)'nin geliştirdiği Matematiksel dil ölçeğinin bulgularında matematik derslerine yönelik öğretimlerin gerçekleştirilmesinde yazılı ve sözlü anlatımların merkezi konumda olduğu, sınıf içinde öğrencilerin gerekli zamanlarda görüşleri alınırken doğru matematiksel terimler, kavramlar ve uygun sembollerin kullanabilmeleri sağlanmalıdır. Buradan da görülmektedir ki öğretmenler derslerinde doğru ve uygun matematiksel dili kullanmaları gerekmekte ayrıca öğrencilerin sınıf içinde görüşlerini belirtirken doğru matematiksel dili doğru bir şekilde kullandıklarından emin olmaları gerekmektedir.

Problem çözme sürecinde öğrencilerin kareköklü ifadelere yönelik yaptıkları hatalar üzerinde durularak konu anlatımının yapıldığı süreçte öğretmenler farklı problem çeşitlerine yer verebilir ayrıca öğrencilerden de faklı ve orijinal problemler kurmalarını isteyebilir. $\mathrm{Bu}$ araştırmada, yalnızca kareköklü ifadeler konusunda matematiksel dil kullanma becerileri incelenmiştir. Farklı sınıf seviyelerinde benzer çalışma yapılarak öğrencilerin matematiksel dil kullanma becerileri hakkında benzer sonuçlara ulaşılıp ulaşılmayacağı araştırılabilir. 


\section{Kaynakça}

Akman, M. ve Erden, M. (2001). Gelisim ve ögrenme. Ankara :Arkadaş Yayınları.

Aydın, S. ve Yeşilyurt, M. (2007). Matematik öğretiminde kullanılan dile ilişkin öğrenci görüşleri. Elektronik Sosyal Bilimler Dergisi. 6 (22), 90-100.

Akarsu, E. (2013). 7. Sinıf Öğrencilerinin cebir ögrenme alanında matematiksel dil kullanımlarının incelenmesi (Yüksek Lisans Tezi). Dokuz Eylül Üniversitesi/Eğitim Bilimleri Enstitüsü, İzmir.

Brodie, K. (1989). Learning mathematics in a second language. Educational Review.41(1), 39-15

Banguoğlu, T. (2007). Türkçenin grameri. Ankara: Türk Dil Kurumu.

Büyüköztürk, Ş., Çakmak, E.K., Akgün, Ö.E., Karadeniz, Ş. ve Demirel, F. (2010). Bilimsel araştırma yöntemleri, Ankara: Pegem Akademi Yayıncılık.

Baykul, Y. (2016). Illkokulda matematik öğretimi. Ankara: Pegem Akademi Yayınc1lık.

Baltalı,C.(2018).Sayılar ve işlemlerle ilgili öğrenci hatalarının incelenmesi (Yayınlanmamış Yüksek Lisans Tezi).Çukurova Üniversitesi/Sosyal Bilimler Enstitüsü.Adana.

Cobb, P., Wood, T. \& Yackel, E. (1994). Discourse, mathematical thinking and classroom practice. In E. A. Forman, N. Minick \& C. Addison Stone (Eds.), Contexts For Learning: Sociocultural Dynamics İn Children's Development (Pp. 91-120). New York: Oxford University Press.

Cengiz, Ö. M. (2006). Reel sayıların öğretiminde bir kısım ortaögretim ögrencilerinin yanılgıları ve yanlışları üzerine bir çalışma (Yayınlanmış Yüksek Lisans Tezi). Atatürk Üniversitesi Fen Bilimleri Enstitüsü, Erzurum.

Çıng1, H.(1994). Örnekleme kuramı(ikinci bask1). Ankara: Hacettepe Üniversitesi Basımevi.

Çalıkoğlu Bali, G. (2002). Matematik öğretiminde dil ölçeği. Hacettepe Üniversitesi Eğitim Fakültesi Dergisi, 23,57-61.

Çakmak, Z. (2013). Sekizinci sını öğrencilerinin istatistik konusundaki matematiksel dil becerilerine ilişkin değişkenlerin yapısal eşitlik modeli ile incelenmesi. (Yayımlanmamış Yüksek Lisans Tezi). Erzincan Üniversitesi, Fen Bilimleri Enstitüsü, Erzincan.

Doğan, M. ve Güner, P. (2012). İlköğretim matematik öğretmen adaylarının matematik alan dilini anlama ve kullanma becerilerinin incelemesi. X. Ulusal Fen Bilimleri Ve Matematik Ĕgitimi Kongresi'nde Sunulmuş Bildiri, Niğde Üniversitesi, Niğde.

Ergin, M. (2008). Türk dil bilgisi. İstanbul: Bayrak yayıncılık.

Emre, E., Yazgan-Sağ, G., Gülkı11k, H., ve Argün, Z. (2017).Matematik öğretmen adaylarının matematiksel dil kullanımları.

Fırat, Z. S. ve Dinçer, Ç. (2018). Okul öncesi öğretmenlerin matematiksel ifadeleri kullanımlarının incelenmesi. Abant İzzet Baysal Üniversitesi Ĕgitim Fakültesi Dergisi, 18(2), 895-914.

Gencan, T. N. (1966). Dil bilgisi. İstanbul: Türk Dil Kurumu.

Güzel, S , Y1lmaz, S . (2020). 8. Sınıf Öğrencilerinin üslü ifadeler konusundaki matematiksel dil kullanım düzeyleri ve dile ilişkin görüşleri . International Journal of Active Learning, 5 (1) , 33-56.

Kavcar, C. (1998). Türk dili ve edebiyatı öğretimi. Ankara Üniversitesi Eğitim Bilimleri Fakültesi Dergisi, 20 (1), 261- 273.

Kaplan, M. (2002). Kültür ve dil. İstanbul: Dergâh yayıncılık.

Köroğlu, H., Yavuz, G. ve Ertem, S. (2003). On birinci sınıf öğrencilerinin geometri dersinde karşılaştıkları bazı kavram yanılgıları ve çözüm önerileri. XII. Eğitim Bilimleri Sempozyumu'nda Sunulmuş Bildiri, Gazi Üniversitesi, Ankara.

Karasar, N. (2011). Bilimsel araştırma yöntemleri. Ankara: Nobel Yayınları.

Kabael, T., ve Baran, A. A. (2016). Matematik öğretmenlerinin matematiksel iletişim becerilerinin gelişimine yönelik farkındalıklarının incelenmesi. Illkogretim Online, 15(3).

Milli Eğitim Bakanlığı.(2013). İlköğretim Matematik Dersi 6-8.sınıflar Öğretim Programı. Ankara:Meb Yayınları.

Milli Eğitim Bakanlığı.(2018). İlköğretim Matematik Dersi 6-8.sinıflar Öğretim Programı. Ankara:Meb Yayınları.

Otterburn, M.K. And Nicholson, A.R.( 1976). The language of (CSE) mathematics, Mathematics In School (5), 18-20. 
Orhun, N., (1998). Cebir öğretiminde aritmetik işlemlerdeki üslü ve köklü çokluklardaki yanılgıların tespiti. Atatürk Üniversitesi 40. Kuruluş Yıldönümü Matematik Sempozyumu. 20-22 Mayıs, Erzurum.

Pazarbaşı, B. N. (2015). İlköğretim matematik ögretmen adaylarının analitik geometri alan dilini kullanma becerileri ve tutumlarının incelenmesi (Yayınlanmış Yüksek Lisans Tezi). Gazi Üniversitesi Eğitim Bilimleri Enstitüsü, Ankara.

Sarama, J. ve Clements, D. H. (2009). Early childhood mathematics education research: Learning Trajectories For Young Children. New York: Routledge.

Ünal, Z. (2013). Yedinci sınıf öğrencilerinin geometri öğrenme alanında matematiksel dil kullanımlarının incelenmesi (Yayınlanmış Doktora Tezi). Dokuz Eylül Üniversitesi/Eğitim Bilimleri Enstitüsü, İzmir.

Yeşildere, S. (2007). İlköğretim matematik öğretmen adaylarının matematiksel alan dilini kullanma yeterlikleri. Boğaziçi üniversitesi Ĕ̈itim Dergisi, 24(2), 61-70.

Yüzerler, S.(2013). 6.Ve 7. Sinıf öğrencilerinin matematiksel dili kullanabilme becerileri(Yayınlanmış Yüksek Lisans Tezi).Necmettin Erbakan Üniversitesi Eğitim Bilimleri Enstitüsü, Konya.

Yaman, Y. ve Ç.Gültekin, D. (2015). Fen ve matematik öğretmen adaylarının matematik öğretiminde kullanılan dile ilişkin görüşlerinin araştırılması. Eğitim ve Öğretim Araştırmaları Dergisi, 4(4), 2146-9199

Yıldız , F. (2016). Altıncı ve yedinci sınıf öğrencilerinin matematiksel sözel, sembolik ve görsel dili anlama ve kullanma becerilerinin (Yayımlanmış Yüksek Lisans Tezi). Marmara Üniversitesi/Eğitim Bilimleri Enstitüsü,İstanbul.

Y1lmaz, S., ve Türkmen, Z. (2019). Yedinci sınıf öğrencilerinin doğrular ve açılar konusunda matematiksel dil kullanım düzeyleri ve dile ilişkin görüşleri. Necatibey Eğitim Fakültesi Elektronik Fen ve Matematik Ĕgitimi Dergisi, 13(1), 31-47.

Zazkis, R. (2000). Using code-switching as a tool for learning mathematical language. For The Learning Of Mathematics, 20(3), 38-43. 


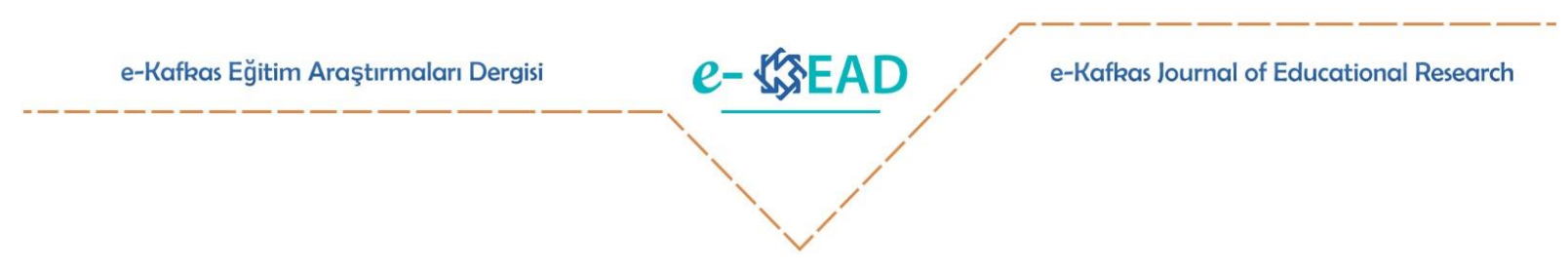

\title{
Eighth Grade Students' Mathematical Language Usage Levels on Square-Root Expressions and Their Views on Language
}

\author{
Süha Yılmaz Sidar Güzel
}

To cite this article: Yılmaz, S. ve Güzel, S. (2020) Sekizinci sınıf öğrencilerinin karaköklü ifadeler konusundaki matematiksel dil kullanım düzeyleri ve dile ilişkin görüşleri. $e$ - Kafkas Eğitim Araştırmaları Dergisi, 7, 282-302. doi: 10.30900/kafkasegt.733078

Research article
Accepted: 29.11 .2020

\section{Introduction}

The infrastructure of people's thoughts is realized through language (Doğan \& Güner, 2012). Mathematics has its own words, terms, language and way of expression, in the same way that some of these words are expressions that exist or are used only in their own inner world, while others may be words used in social life (Aydin \& Yeşilyurt, 2007). The words that make up the sentences add different meanings to the sentence. Therefore, while teaching mathematics and communicating in the classroom, it is necessary to examine the structure of the language, the way it is used and also the features of the language because language is one of the important tools in the realization of communication (Yavuz \& Gültekin, 2015). Language is not always a sound phenomenon, but functions for the use of signs. Baykul (2016) defined mathematics as a language that includes some symbols, a resource we need in order to understand the world we live in and improve the environment we live in, and a system that makes the individual think logically. According to Brodie (1989), language is a precondition for thoughts, as well as enabling people to question mathematical structures and operations, express their thoughts comfortably and clearly, and verify the results they find, in the simplest sense, language is a communication tool.

Philosophers, linguists, sociologists, and psychologists have defined language in different ways. Looking at the definitions: While Ergin (2008) states that language is a natural element, it provides people to understand, has its own rules and changes and develops within these rules, and when we do not have information about when the foundation is laid, Banguoğlu defines it as an institution made of voices. (2007), on the other hand, stated that a person can express their wishes by making various signs, but the most effective means of expression is language, stating that it is a system of vocal signals that people use to express their thoughts, desires or goals. Gencan (1966) stated that language is the mirror of our inner self. Kavcar (1988), on the other hand, defined language as the thought tool that brings people closer to each other, the basic element of culture and the most important element that makes society a nation. Kaplan (2002) stated that language guides an individual's emotions, thoughts and imagination. Expressions or sentences are used for communication through language, and words are used for sentences, and concepts are defined by combining words (Akman \& Erden, 2001). It is only possible for people to communicate well with each other if they use the same language. When some mathematical terms and concepts are not used with the correct content, students can misunderstand these terms and concepts and make them different meanings, so it is very important that the mathematical concepts used by teachers have the same meaning for the student (Çalıkoğlu Bali, 2002). 
When the general objectives of the Mathematics Course Teaching Program in line with the General Purposes and Basic Principles determined in the Basic Law of National Education No.1739 are examined, it is seen that the meaning and language of mathematics will be used to make sense of the relationships between human-object, object-object, and mathematical thoughts and logic. It is stated that he can use mathematical terminology and mathematical language correctly in order to explain and share these thoughts (MEB, 2018).

It can be said that the field language is effective in using the concepts correctly and in strengthening the relationship between the concepts (Köroğlu, Yavuz, ve Ertem, 2003). Emre, Yazgan-Sağ, Gülk1lık, and Argün (2017) aimed to reveal which of the symbolic or verbal forms of language that pre-service teachers focused on while making sense of and using concepts, while preservice teachers mostly used symbolic language when solving problems, but they mainly used verbal language when making sense of mathematical concepts. has been determined. Even though the verbal and symbolic languages of mathematics are defined differently, the symbolic and verbal language forms widely used in mathematics are intertwined. Multiple representations (eg verbal expression, written expression, pictures, graphics and concrete models) have been reported to be effective in the use of mathematical language (MEB, 2013). Mathematical language, which plays an important role in understanding mathematical terms, concepts or words, is considered an important skill in mathematics education (Sarama \& Clements, 2009). In the qualitative study titled "Investigation of Mathematics Teachers' Awareness for the Development of Mathematical Communication Skills" conducted by Kabael and Baran (2016) with middle school mathematics teachers, all teachers were aware that mathematics is a language, and that the correct and effective use of mathematical language should be an example to students in this way. On the other hand, they reached the conclusion that not all teachers were aware of the development of mathematical communication skills. Otterburn and Nicholson (1976) found that students knew many mathematical terms, but could not explain most of the mathematical concepts that teachers frequently used. The results of the study show that they were not aware of this inadequacy, and also when the students could not fully express the given mathematical concepts and did not understand and use mathematical concepts.

\section{The purpose of the study}

The aim of this study was to determine the eighth grade students' ability to use mathematical language in terms of square-rooted expressions and to examine their views on the use of mathematical language in terms of various variables, as well as to examine the relationship between their level of using mathematical language and their views on mathematical language use. For this purpose, it has been tried to find answers to the sub-problems below.

\section{Sub Problems}

1) What are the levels of eighth grade students' ability to use mathematical language about square-root expressions?

2) Is there a relationship between eighth grade students' level of mathematical language use in square-rooted expressions and their math grade averages?

3) Do eighth grade students' level of using mathematical language in square-rooted expressions show a statistically significant difference according to their gender?

4) What are the opinions of eighth grade students on mathematical language use?

5) Is there a significant relationship between eighth grade students' ability to use mathematical language on square-rooted expressions and their views on mathematical language use?

6) Is there a significant relationship between eighth grade students' views on mathematical language use and their math grade point averages?

7) Is there a statistically significant difference between eighth grade students' opinions on mathematical language use and their gender? 


\section{Method}

\section{Research model}

Descriptive Scanning Model, one of the quantitative research designs, was used in the study. Studies created according to the Descriptive Screening Model are studies conducted to determine certain characteristics of a group (Büyüköztürk, Çakmak, Akgün, Karadeniz, \& Demirel, 2018). In other words, it is aimed to determine the existing situation. Since the relationship between the opinions of the participants and the language level of the field is also examined in the study, the research is also a relational survey study. In the relational screening study, the existence and / or degree of the co-change between two or more variables is examined without any intervention to the variables (Karasar, 2011).

\section{Sampling}

The sample of the study consists of a total of 114 eighth grade students studying at 2 different public schools affiliated to the Directorate of National Education in a province in the Eastern Anatolia Region. In the selection of the sample of the study, the simple random sampling method, which is included in the probability-based sampling method, was preferred. In simple random sampling, each sampling unit is given an equal probability of being selected, and this sampling method is based on choosing each sample in space with equal probability (Çıngı, 1994).

\section{Data Collection Tool}

Two different data collection tools were used for research purposes. The first of these; An achievement test consisting of 22 open-ended questions was developed by the researcher to examine the skills of eighth grade students studying in secondary school in using mathematical language in terms of square-rooted expressions in the field of learning numbers and operations. The mathematical language scale used in the study is the mathematical language scale developed by Akarsu (2013) using the scale developed by Çalıkoğlu Bali (2002). In this scale, 4 dimensions are defined and these are "written expression and written assignments, symbolic expression, problem-posing and oral expression".

\section{Data Analysis}

Data were tested by using the SPSS 23.0 package program, the frequency distribution, descriptive statistics, correlation and independent samples t test.

\section{Findings}

As a result of the study, it was determined that there are deficiencies in the use of mathematical language in terms of square-rooted expressions and these need to be improved, their level of mathematical language use does not differ significantly according to gender, and there is a moderate positive relationship between mathematical language use levels and mathematics achievement. In addition, it was observed that the students had a positive opinion on the use of mathematical language, there was no significant difference in terms of gender variable, and there was a low level of relationship between their views on mathematical language use and their mathematics achievement.

\section{Discussion, Conclusion and Recommendations}

In the literature, studies examining the misconceptions that exist mostly about radical expressions were found.The learning area of numbers and operations is one of the main issues associated with other learning areas, and it is not possible to grasp other issues unless the contents of the content are fully comprehended.This leads us to the conclusion that deep studies should be made on the use of both students' subject information and mathematical language on square root expressions.Mathematics, which has a spiral structure, has a connection between the topics in its 
content.In the study, it is seen that the students who are insufficient in explicit expressions also made mistakes in square root expressions. It was observed that they made generalizations in certain basic rules that existed in general, and they fell into misconceptions and mistakes. When the square rooted expressions' success test was examined, it was understood that they could not fully grasp the rules, so the teachers should guide the students to reach the rules by themselves instead of waiting for the ready mathematical rules to be memorized. 